\title{
Nitrogen Application Rate and Genotype Effects on Switchgrass Production and Chemical Characteristics
}

\author{
Ramdeo Seepaul', Bisoondat Macoon ${ }^{2}$, K. Raja Reddy ${ }^{3}$, William B. Evans ${ }^{4}$ \\ ${ }^{1}$ North Florida Research \& Education Center, University of Florida, Quincy, FL, USA \\ ${ }^{2}$ Mississippi State University, Central MS REC, Raymond, MS, USA \\ ${ }^{3}$ Department of Plant and Soil Sciences, Mississippi State University, Mississippi State, MS, USA \\ ${ }^{4}$ Truck Crops Branch Experiment Station, Mississippi State University, Crystal Springs, MS, USA \\ Email:rseepaul216@ufl.edu,bmacoon@ra.msstate.edu,krreddy@pss.msstate.edu,wbe@ra.msstate.edu
}

Received 18 December 2015; accepted 20 March 2016; published 23 March 2016

Copyright (C) 2016 by authors and Scientific Research Publishing Inc.

This work is licensed under the Creative Commons Attribution International License (CC BY).

http://creativecommons.org/licenses/by/4.0/

(c) (i) Open Access

\begin{abstract}
Switchgrass (Panicum virgatum L.) is considered as an important biofuel crop but further studies on factors that may have an effect on agronomic performance and energy attributes are needed to help elucidate management strategies for the crop. A 2-yr field study at the Brown Loam Branch Experiment Station, Raymond, Mississippi, USA, quantified the effects of four $\mathrm{N}$ application rates and four genotypes on biomass yield, ethanol yield, and nutrient removal of switchgrass. Biomass yield response to $\mathrm{N}$ rate was linear in 2008 and quadratic in 2009. Among genotypes, biomass yield averaged across $\mathrm{N}$ rate and years, ranked lowland NF/GA992 $\left(13.9 \mathrm{Mg} \cdot \mathrm{ha}^{-1}\right)=$ lowland NF/ GA001 (13.4 Mg.ha-1) > lowland Alamo (11.5 Mg.ha-1) > upland Cave-in-Rock (6.1 Mg.ha-1). There was no effect of $\mathrm{N}$ rate on tissue mineral concentrations but there was an $\mathrm{N}$ rate effect on $\mathrm{Ca}$ and Mg removal. Also, $\mathrm{N}$ use (biomass yield produced per unit $\mathrm{N}$ applied) and recovery ( $\mathrm{N}$ removed in biomass) declined as $\mathrm{N}$ rate increased. Total ethanol yield was the greatest in Alamo $\left(165.8 \mathrm{~L} \cdot \mathrm{Mg}^{-1}\right)$ and averaged $162.0 \mathrm{~L} \cdot \mathrm{Mg}^{-1}$ for the other three genotypes. Total ethanol production was related more to biomass yield than chemical composition differences and was similar among lowland genotypes but different from Cave-in-Rock in 2008 (1.7 vs. $\left.0.9 \mathrm{~kL} \cdot \mathrm{ha}^{-1}\right)$ and 2009 (2.6 vs. $\left.1.1 \mathrm{~kL} \cdot \mathrm{ha}^{-1}\right)$. Feedstock grown from lowland Alamo, NF/GA001 or NF/GA992 produced greater biomass yield and ethanol as well as greater $\mathrm{N}$ use efficiency and recovery. These results indicate that there is opportunity to increase switchgrass biomass production through genotype selection and $\mathrm{N}$ management.
\end{abstract}

\section{Keywords}

Nitrogen Use, Biofuel, Ethanol, Nutrient Removal, Biomass 


\section{Introduction}

Biofuel crops are expected to contribute substantially towards energy security, environmental stewardship, and economic gains in the USA. Environmental benefits to be realized include greenhouse gas reduction, carbonneutral biofuel production, use of and reclamation of marginal lands and relatively low-input production systems [1]. Switchgrass was selected for research and development as a dedicated bioenergy crop for the lignocellulosic biofuel industry in 1992 by the U.S. Department of Energy's Bioenergy Feedstock Development Program [2]. Optimizing and sustaining bioenergy crop production systems requires knowledge of the system itself and factors that have an effect on sustainable productivity.

Nutrient uptake and loss from production sites are important issues for high biomass producing crops such as switchgrass. Nitrogen has an effect on crop growth, development, and physiological processes and determines crop productivity, chemical characteristics, and profitability. It is one of the most challenging nutrients to manage effectively. In many agroecosystems, a very substantial portion of applied $\mathrm{N}$ is lost from soil to ground water, rivers, and oceans [3] [4], because crop plants only convert 30\% - 40\% of this applied $\mathrm{N}$ to useful products [5]. In lignocellulosic crops, it is important to minimize feedstock nutrient concentration that may contribute to ash at combustion causing slagging and fouling of processing equipment as well as reduced efficiency of ethanol conversion processes. Therefore, a high quality biofuel feedstock should have minimal moisture, low $\mathrm{N}$ and ash contents, minimal undesirable mineral concentration with high cellulose [6] [7]. This requirement will require judicial management of $\mathrm{N}$ application during crop production.

Nitrogen removal in the biomass can determine the fertilizer requirements of switchgrass [8]. The quantity of $\mathrm{N}$ removed in harvested biomass depends on the genotype, quantity of $\mathrm{N}$ applied, harvest frequency and timing, and temporal weather variability. Lowland cultivars are more responsive to applied $\mathrm{N}$ [9] [10], later maturing, and produce greater biomass than upland cultivars in many southern US environments.

Removal of $\mathrm{N}$ and other nutrients is a function of biomass yield and tissue $\mathrm{N}$ concentration [11]. Incremental increases in $\mathrm{N}$ application invariably increase switchgrass biomass yield and tissue $\mathrm{N}$ concentration [12]. The magnitude of increase usually follows the law of diminishing returns with the response to incremental increase being progressively less with each increase in $\mathrm{N}$ application [13]. At $120 \mathrm{~kg} \mathrm{~N}^{-1}$, the amount of $\mathrm{N}$ removed was similar to the amount of $\mathrm{N}$ applied and rates above this level led to increased soil nitrate- $\mathrm{N}$ levels [11]. In Alamo, $\mathrm{N}$ removal was $50 \%$ greater than the amount of $\mathrm{N}$ applied, attributed to the ability of switchgrass to sequester $\mathrm{N}$ possibly through symbiotic relationships with soil or plant microbes [9]. Accumulation of $\mathrm{P}, \mathrm{K}$, and other plant nutrients in switchgrass is additional factors in understanding sustainable production of quality feedstock. These parameters and their interactions with $\mathrm{N}$ application and switchgrass genotypes have not been studied extensively.

Management decisions effects on yield and nutrient balance of production systems as well as on biomass quality and ethanol yield also have not been adequately addressed. Biomass feedstock composition varies with harvest date, location, and fertility management [13]. Previous reports on biomass quality reported mainly cell wall composition traits but not characterization of ethanol components or quantification of ethanol yield [6] [7]. Ethanol production via fermentation can be achieved from direct conversion of sugars and enzyme-mediated hydrolysis of starch or cellulose. Lignocellulose is a complex of cellulose, hemicellulose and lignin and therefore requires additional process steps for ethanol conversion. These steps include delignification to release cellulose and hemicellulose, depolymerisation of cellulose and hemicellulose to produce fermentable sugars before fermentation to produce ethanol. Simultaneous saccharification and fermentation (SSF) is one process option for the production of ethanol from lignocellulosic biomass and integrates the enzymatic hydrolysis of cellulose to glucose and fermentation of glucose to ethanol. The SSF procedure requires complex fermentation assays and compositional analysis of biomass. With the development of near-infrared spectroscopy (NIRS), however, it has become analytically acceptable to determine biomass composition using equations developed by the USDAARS NIRS Consortium [14]. This experiment quantified the effects of $\mathrm{N}$ rates and switchgrass genotypes on nutrient removal rates, chemical composition, and ethanol yield. These findings will have direct implications for nutrient management and feedstock quality control in switchgrass production systems in the U.S. Midsouth.

A systematic approach to nutrient management requires an understanding of nutrient removal capacities, biomass production and feedstock quality. Understanding and quantifying nutrient removal in switchgrass production systems can aid in cultivar selection, feedstock quality control, optimized agronomic resource management, and reduction in nutrient loss. Quantitative information required for optimizing nutrient dynamics, yield, 
and quality in switchgrass is incomplete and inadequate. The objective of this study was to determine the effects of $\mathrm{N}$ application and genotypes on biomass production and nutrient removal, including micro-nutrients, and biomass and ethanol yield in switchgrass grown in a site that represents the U.S Midsouth.

\section{Materials and Methods}

\subsection{Study Site}

This field study was planted in May 2006, and treatment imposition and data collection were conducted from 2008 through 2009 growing seasons at the Brown Loam Branch Experiment Station, Raymond, MS (32 $15^{\prime} \mathrm{N}$, $90^{\circ} 30^{\prime} \mathrm{W}$ ). The soil at the site is a Loring silt loam (fine-silty, mixed, thermic Typic Fragiudalfs) characterized by $2 \%$ to $5 \%$ slopes, eroded, moderately well-drained with a fragipan.

\subsection{Weather Conditions}

Weather data were collected from the climate station located at the research site. Growing season (April-November) precipitation for $2008(1023 \mathrm{~mm})$ and $2009(955 \mathrm{~mm})$ was more than the 30-yr average $(924 \mathrm{~mm})$. March 2008 precipitation $(71 \mathrm{~mm})$ was the driest March recorded at the location, while March 2009 (235 mm) precipitation was 230\% above March 2008 and 69\% more than the 30-yr average March precipitation (139 mm) (Table 1). Mean air temperature for $2008\left(21.6^{\circ} \mathrm{C}\right)$ and $2009\left(21.9^{\circ} \mathrm{C}\right)$ was comparable to the 30-yraverage temperature of $21.8^{\circ} \mathrm{C}$ (Table 1$)$.

\subsection{Treatments and Experimental Design}

Following seedbed preparation in May 2006, genotypes were seeded with a small-plot planter (Kincaid Equipment and Manufacturing, Haven, KS) at a rate of $5.6 \mathrm{~kg}$ pure live seed $\mathrm{ha}^{-1}$ in seven rows $22 \mathrm{~cm}$ apart. The experiment was a split-plot arrangement of a randomized complete block design with four replications. Treatments were switchgrass genotypes (three related lowland genotypes: Alamo, NF/GA001, NF/GA992 and one upland genotype: Cave-in-Rock) as whole plots and $\mathrm{N}$ rates $\left(0,80,160\right.$, and $\left.240 \mathrm{~kg} \cdot \mathrm{ha}^{-1} \mathrm{~N}\right)$ as subplots. In late fall of each year, (including the year prior to the initiation of this experiment) all plots were harvested at a10-cm stubble

Table 1. Monthly precipitation and mean monthly air temperature for 2008 and 2009 and the 30-yr average (1979-2009) at the Brown Loam Branch Experiment Station, Raymond, MS.

\begin{tabular}{|c|c|c|c|c|c|c|}
\hline \multirow{2}{*}{ Month } & \multicolumn{3}{|c|}{ Precipitation (mm) } & \multicolumn{3}{|c|}{ Air Temperature $\left({ }^{\circ} \mathrm{C}\right)$} \\
\hline & 2008 & 2009 & 30-yr avg. & 2008 & 2009 & 30-yr avg. \\
\hline January & 93 & 134 & 136 & 7.9 & 7.5 & 7.4 \\
\hline February & 175 & 96 & 129 & 9.7 & 9.7 & 9.6 \\
\hline March & 71 & 235 & 139 & 14.7 & 15.3 & 13.8 \\
\hline April & 99 & 94 & 125 & 17.1 & 16.9 & 17.7 \\
\hline May & 103 & 89 & 119 & 21.0 & 22.2 & 22.3 \\
\hline June & 50 & 17 & 129 & 26.8 & 26.6 & 24.3 \\
\hline July & 47 & 187 & 104 & 28.0 & 26.2 & 27.4 \\
\hline August & 265 & 98 & 114 & 26.1 & 26.2 & 27.2 \\
\hline September & 260 & 140 & 91 & 23.7 & 24.7 & 24.1 \\
\hline October & 40 & 309 & 109 & 17.8 & 17.9 & 18.4 \\
\hline November & 159 & 22 & 134 & 12.4 & 14.4 & 13.3 \\
\hline December & 227 & 180 & 137 & 9.0 & 7.3 & 8.9 \\
\hline
\end{tabular}


height. In early May of both study years, fertilizer was applied to subplots according to treatment in a single broadcast application of urea (46-0-0) by hand. No chemical weed and pest control or supplemental irrigation was applied during the experiment period.

\subsection{Data Collection}

To determine biomass yield, a $1 \times 0.5 \mathrm{~m}$ area in the center of each subplot was cut to a 10 -cm stubble height in November of each year using 7.2 volt cordless battery-operated hand-held shears (Stanley Black and Decker, New Britain, CT). The total harvested material was weighed fresh and an approximately 1-kg subsample was taken and dried in a forced-air oven at $55^{\circ} \mathrm{C}$ to $60^{\circ} \mathrm{C}$ for $72 \mathrm{~h}$ or until constant weight was achieved in order to determine dry matter (DM) concentration. A second subsample taken from the harvested material was dried similarly and ground to pass a 1-mm stainless steel screen using a Wiley Mill (Model 4; Thomas Scientific, Swedesboro, NJ). Analysis of N, P, K, Ca, and Mg was done at the Mississippi State University Soil Testing Laboratory. A homogenized subsample was analyzed for fiber constituents and sugar composition by NIRS using a FOSS NIRSystems Model 6500 spectrophotometer (FOSS Industries, Silver Spring, MD). Samples were scanned using the FOSS ISIscan software Version 4.4 (Infrasoft International) with grass hay and switchgrass prediction equations (Vogel et al., 2011) developed by the NIRS Forage and Feed Testing Consortium (Hillsboro, WI). Calibration statistics used were developed by Vogel et al. [14]. Hemicellulose and cellulose concentrations were calculated as the difference between predicted neutral detergent fiber (NDF) and acid detergent fiber (ADF) concentrations and the difference between predicted ADF and acid detergent lignin (ADL) concentrations, respectively.

\subsection{Calculations and Statistical Analysis}

Nutrient removal was calculated by multiplying the biomass yield by elemental tissue concentration. Nitrogen use efficiency (NUE; kg biomass $\mathrm{kg}^{-1} \mathrm{~N}$ ) was calculated as the ratio of the increase of biomass harvested that resulted from $\mathrm{N}$ fertilizer application to the $0 \mathrm{~N}$ control. Apparent $\mathrm{N}$ Recovery (ANR; \%) was calculated as the ratio of $\mathrm{N}$ removed from $\mathrm{N}$ fertilizer application to the $0 \mathrm{~N}$ control expressed as a percent.

Ethanol yield was calculated following the methods of Vogel et al. (2011) who determined ethanol per gram

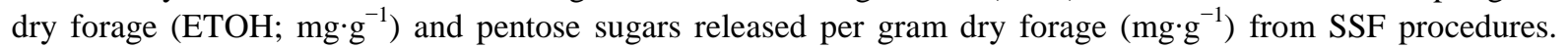
Actual ethanol yield via SSF was calculated using the ETOH result. In this procedure, the yeast used to ferment the released sugars cannot ferment pentose sugars, so ETOH was only from released hexoses. Given this, the equation below to calculate total ethanol yield (TEY) accounts for ethanol yield from SSF-released glucose from biomass using the calculation ETOH $\times 1.267$, and the theoretical ethanol yield (TTEY) from pentose sugars, arabinose (ARA), and xylose (XYL) using the calculation (ARA + XYL) × $0.579 \times 1.267$.

Total ethanol yield $\left(\mathrm{L} \cdot \mathrm{Mg}^{-1}\right)$ is a summation:

$$
\mathrm{TEY}=(\mathrm{ETOH} \times 1.267)+((\mathrm{ARA}+\mathrm{XYL}) \times 0.579 \times 1.267)
$$

The TTEY from all biomass hexoses considers concentrations of ARA, fructose (FRU), galactose (GAL), glucose (GLC), mannose (MAN), soluble glucose (GLCS), starch (STA), and sucrose (SUC) and was calculated (assuming 100\% conversion) as [(MAN + GAL + GLC + STA $) \times 0.57+($ GLCS + FRU) $\times 0.51+(0.537 \mathrm{SUC}) \times$ 1.267]. Theoretical ethanol yield from pentose sugars was calculated as (ARA + XYL) × 0.579 × 1.267.

The equation to calculate TTEY $\left(\mathrm{L} \cdot \mathrm{Mg}^{-1}\right)$ is the summation of the two:

$$
\begin{aligned}
\mathrm{TTEY}= & {[(((\mathrm{MAN}+\mathrm{GAL}+\mathrm{GLC}+\mathrm{STA}) \times 0.57)+(\mathrm{GLCS}+\mathrm{FRU}) \times 0.51)+(\mathrm{SUC} \times 0.537) \times 1.267] } \\
& +[(\mathrm{ARA}+\mathrm{XYL}) \times 0.579 \times 1.267]
\end{aligned}
$$

Total ethanol production (TEP) was calculated as TEY $\times$ biomass yield. Similarly, total theoretical ethanol production (TTEP) was calculated as TTEY $\times$ biomass yield.

The data were analyzed by fitting mixed models with repeated measures using PROC MIXED of SAS [15]. Genotype, $\mathrm{N}$ application rate, year, and their interactions were considered fixed effects while replication $\times$ year was considered a random effect. Year was considered as a repeated measure and responses were considered different at the 0.05 probability level. Means were separated using the PDIFF option. Relationships among biomass 
yield, fiber properties, and sugar composition were explored using correlation analysis. When correlations were detected, regressions were performed using PROC REG of SAS to quantify the relationship.

\section{Results and Discussion}

\subsection{Biomass Yield}

There was a year $\times \mathrm{N}$ rate interaction $(P=0.009)$ effect on annual biomass yield. Generally, biomass yield during 2009 was greater than 2008; however, the responses within year were different (Figure 1). In 2008, biomass yield increased linearly with $\mathrm{N}$ rate $(P=0.013)$, but in 2009 , the response was quadratic $(P<0.001)$. There was also a year $\times$ genotype interaction effect on annual biomass yield $(P=0.019)$. The interaction occurred partly because of differences in the patterns of means separation among genotypes within years. In 2008, NF/GA001 (9.3 Mg $\left.\cdot \mathrm{ha}^{-1}\right)$, NF/GA992 (8.4 Mg.ha $\left.{ }^{-1}\right)$ and Alamo $\left(7.9 \mathrm{Mg} \cdot \mathrm{ha}^{-1}\right.$ ) had similar biomass yield but in 2009, NF/ GA001 (13.8 Mg $\left.\cdot \mathrm{ha}^{-1}\right)$ and NF/GA992 $\left(15.0 \mathrm{Mg} \cdot \mathrm{ha}^{-1}\right)$ were greater than that of Alamo $\left(12.6 \mathrm{Mg} \cdot \mathrm{ha}^{-1}\right)$. Cave-in-

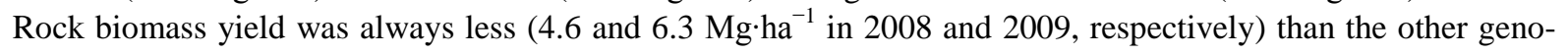
types. Other studies have reported variation in biomass yield responses across years that vary markedly [8] [12] [16].

Biomass yield increases ranged from 58\% [8] to 85\% [7] in the second year of harvest in 1-yr switchgrass stands. Data from those studies indicate that response trends for biomass yield with age of stand are similar across geographic locations although absolute values vary. Differences in absolute values of responses observed across location may be attributable to early-season precipitation variability between years [17], inherent soil physical and chemical properties, photoperiodism, harvest frequency, as well as age-related stand productivity potential. Interannual biomass variability is correlated with growing season rainfall [12]. Switchgrass biomass was reported to increase with stand age up to $3 \mathrm{yr}$, plateau at around 4 to $5 \mathrm{yr}$ and decline thereafter [8] [12] [18]. The biomass yield differences between years observed in this study may have been influenced, in part, by the greater precipitation in March 2009.

Averaged across genotypes, biomass yield increased by $29 \%$ (2008) and $69 \%$ (2009) at $80 \mathrm{~kg} \mathrm{~N}$ ha $^{-1}$ compared to the control, but there was no further increases with the additional $\mathrm{N}$ rates (Figure 1). Lowland cultivars are more responsive to $\mathrm{N}$ application and have greater growth potential than upland cultivars due to mid-season growth vigor and delayed maturity [10]. In southern locations such as in this study, Cave-in-Rock, a northern

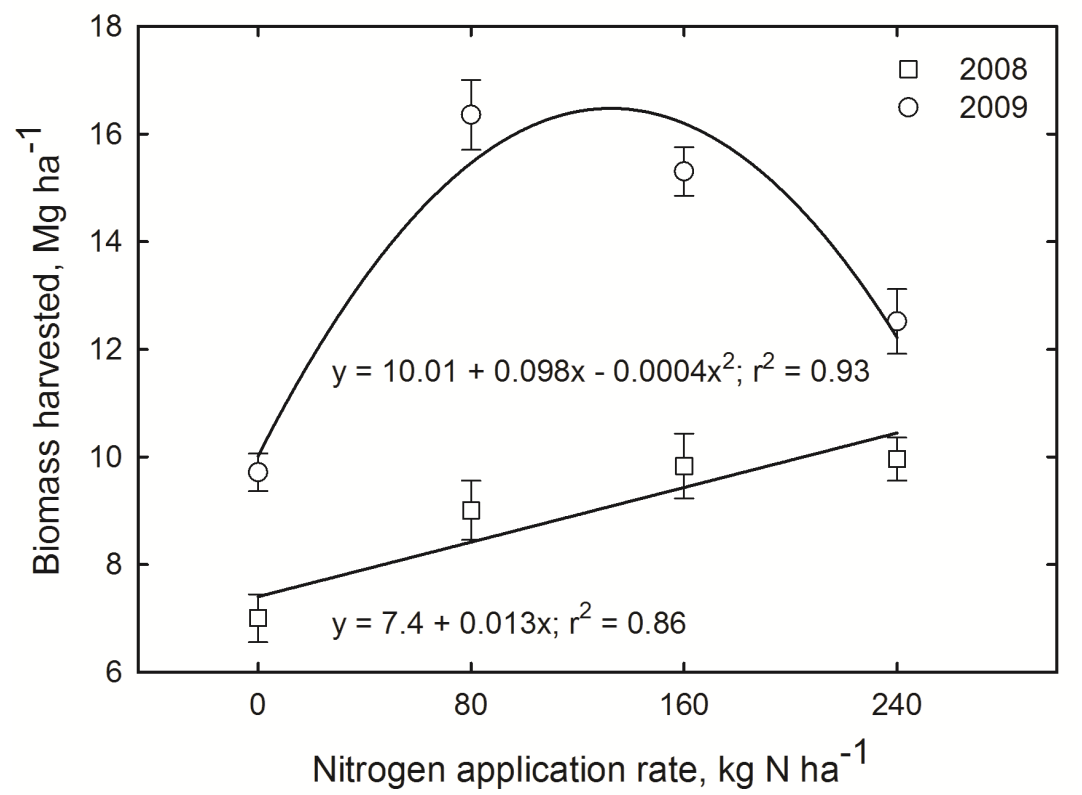

Figure 1. Year $\times \mathrm{N}$ rate interaction effects on biomass yield of switchgrass grown during 2008 and 2009 at the Brown Loam Branch Experiment Station, Raymond, MS. 
upland variety, is expected to produce less than Alamo and the experimental lines (NF/GA001 and NF/GA992) [10] [19]. The breeding lines NF/GA001 and NF/GA992 are selections from parental Alamo populations, possibly explaining why there was no difference in biomass yield response to $\mathrm{N}$ application rate among these three related genotypes.

\subsection{Tissue Nutrient Concentrations}

There was no effect of genotype, $\mathrm{N}$ rate or their interactions on tissue $\mathrm{N}$ concentration $(P>0.5)$, which ranged from 7.16 to $8.15 \mathrm{~g} \cdot \mathrm{kg}^{-1}$ with a mean of $7.72 \mathrm{~g} \cdot \mathrm{kg}^{-1}$ (data not shown). Other studies have reported that tissue $\mathrm{N}$ concentration increased with $\mathrm{N}$ application rate (Guretzky et al., 2011; Jung et al., 1990; Madakadze et al., 1999). The average tissue $\mathrm{N}$ concentration $\left(7.64 \mathrm{~g}_{\mathrm{kg}}^{-1}\right)$ among genotypes at the zero $\mathrm{N}$ rate was within range of $8.2 \mathrm{~g} \cdot \mathrm{kg}^{-1}$ reported by Jung et al. [20] but more than $4.3 \mathrm{~g} \cdot \mathrm{kg}^{-1}$ reported by Guretzky et al. [17] when no N was applied. These differences may result from inherent soil physicochemical properties, the plants ability to sequester $\mathrm{N}$ deeply in the soil profile through its extensive root system, and time of harvest. Since $\mathrm{N}$ is mobile in the plant and is translocated from shoots to roots at the onset of senescence, harvesting after senescence will reduce tissue $\mathrm{N}$ concentration [16].

There was no effect of $\mathrm{N}$ rate on $\mathrm{P}, \mathrm{K}, \mathrm{Ca}, \mathrm{Mg}$, and $\mathrm{S}$ tissue concentrations $(P>0.5)$; however, there was a year $\times$ genotype interaction on $\mathrm{P}, \mathrm{K}, \mathrm{Ca}$, and $\mathrm{Mg}$ concentrations $(P<0.05)$. Tissue $\mathrm{P}$ concentration of Cave-in-Rock and NF/GA992 decreased from 2008 to 2009 (Table 2) but did not change with year in the other two genotypes. Across years and genotypes, $\mathrm{P}$ concentration ranged from 0.33 to $0.85 \mathrm{~g} \cdot \mathrm{kg}^{-1}$, compared to the 0.7 to $0.9 \mathrm{~g} \cdot \mathrm{kg}^{-1}$ reported by Guretzky et al. [17] and 0.90 to $1.50 \mathrm{~g} \cdot \mathrm{kg}^{-1}$ reported by Propheter et al. [21]. Tissue $\mathrm{K}$ concentration was greater in 2008 than 2009 (Table 2). In 2008, K concentration was greater in Cave-in-Rock than the other genotypes but was similar across genotypes in 2009. Tissue $\mathrm{P}$ and $\mathrm{K}$ concentrations were less than those reported previously [17] [21]. Tissue Ca concentration within all genotypes was greater in 2008 than 2009 and among genotypes within both years, was greater for Cave-in-Rock than the other genotypes (Table 2). Tissue Mg concentration in 2008 was greater than 2009 for all genotypes except NF/GA992, which had similar concentration both years. Among genotypes, Mg concentrations were similar in 2008 but the magnitude of decrease in 2009 was larger for Cave-in-Rock than the other genotypes, resulting in it being the least among genotypes (Table 2). Tissue S concentration was greater in 2008 than 2009 (Table 2). We inferred from the results that $\mathrm{N}$ fertility did not have an effect on tissue macronutrient concentrations in switchgrass grown in a fertile soil. Production using a particular genotype probably will require specific nutrient management in soils with low levels of plant available nutrients.

\subsection{Nutrient Removal}

There were $\mathrm{N}$ rate $(P=0.0009)$, genotype $(P<0.0001)$, and year $(P=0.0184)$ main effects on $\mathrm{N}$ removal but no

Table 2. Means of P, K, Ca, Mg, and S tissue concentrations among switchgrass genotypes during the 2008 and 2009 growing seasons at Brown Loam Branch Experiment Station, Raymond, MS.

\begin{tabular}{|c|c|c|c|c|c|c|c|c|c|c|}
\hline \multirow{3}{*}{ Genotype } & \multicolumn{10}{|c|}{ Nutrient Concentration } \\
\hline & \multicolumn{2}{|c|}{$\mathrm{P}$} & \multicolumn{2}{|c|}{$\mathrm{K}$} & \multicolumn{2}{|c|}{$\mathrm{Ca}$} & \multicolumn{2}{|c|}{$\mathrm{Mg}$} & \multicolumn{2}{|c|}{ S } \\
\hline & 2008 & 2009 & 2008 & 2009 & 2008 & 2009 & 2008 & 2009 & 2008 & 2009 \\
\hline & & & & & $\mathrm{g} \cdot \mathrm{kg}^{-1}$ & & & & & \\
\hline Alamo & $0.56 \mathrm{bA}^{\dagger}$ & $0.49 \mathrm{aA}$ & $1.88 \mathrm{bA}$ & $0.27 \mathrm{aB}$ & $1.88 \mathrm{bA}$ & $1.46 \mathrm{bB}$ & $1.69 \mathrm{aA}$ & $0.94 \mathrm{aB}$ & 0.40 & 0.25 \\
\hline Cave-in-Rock & $0.85 \mathrm{aA}$ & $0.52 \mathrm{aB}$ & $2.51 \mathrm{aA}$ & $0.31 \mathrm{aB}$ & $3.05 \mathrm{aA}$ & $2.10 \mathrm{aB}$ & $1.82 \mathrm{aA}$ & $0.76 \mathrm{bB}$ & 0.44 & 0.26 \\
\hline NF/GA001 & 0.39 cA & $0.46 \mathrm{abA}$ & $1.69 \mathrm{bA}$ & $0.36 \mathrm{aB}$ & $1.90 \mathrm{bA}$ & $1.38 \mathrm{bB}$ & $1.50 \mathrm{aA}$ & $0.85 \mathrm{aB}$ & 0.41 & 0.39 \\
\hline NF/GA992 & $0.61 \mathrm{bA}$ & $0.33 \mathrm{bB}$ & $1.84 \mathrm{bA}$ & $0.27 \mathrm{aB}$ & $1.74 \mathrm{bA}$ & $1.36 \mathrm{bB}$ & $1.38 \mathrm{aA}$ & $1.16 \mathrm{aA}$ & 0.37 & 0.27 \\
\hline Mean & & & & & & & & & $0.40 \mathrm{~A}$ & $0.29 \mathrm{~B}$ \\
\hline SEM & 0.08 & 0.02 & 0.09 & 0.01 & 0.15 & 0.09 & 0.05 & 0.04 & 0.01 & 0.02 \\
\hline
\end{tabular}

${ }^{\dagger}$ Within column, means followed by the same lowercase letters, and within rows, means followed by the same uppercase letters are not different $(P>$ 0.05 ) using the pairwise difference option (PDIFF) in SAS. 
interactions $(P>0.05)$ were detected. Among genotypes, $\mathrm{N}$ removal followed the same pattern as biomass yield responses. Among Alamo, NF/GA001 and NF/GA992, $\mathrm{N}$ removal was quadratic in response to $\mathrm{N}$ application rate $\left(\mathrm{y}=74.44+0.59 \mathrm{x}-0.002 \mathrm{x}^{2}, r^{2}=0.80\right)$ and linear for Cave-in-Rock $\left(\mathrm{y}=32.51+0.123 \mathrm{x} ; r^{2}=0.99\right)$ (Figure 2). Averaged across genotypes and $\mathrm{N}$ rate, $2009 \mathrm{~N}$ removal $\left(99.4 \mathrm{~kg} \mathrm{~N} \mathrm{ha}^{-1}\right)$ was greater than 2008 (72.5 $\mathrm{kg} \cdot \mathrm{ha}^{-1}$ ). The increase in $\mathrm{N}$ removal across years appears to be related to the $54 \%$ increase in biomass yield from 2008 to 2009.

There was no effect of tissue $\mathrm{N}$ concentration on $\mathrm{N}$ removal, possibly because of post maturity shoot to root translocation of $\mathrm{N}$ [16]. Jung et al. [20] reported that $\mathrm{N}$ removal increased by $69 \%$ with application of $\mathrm{N}$ from 0 $\left(48.8 \mathrm{~kg} \cdot \mathrm{ha}^{-1}\right)$ to $75 \mathrm{~kg} \cdot \mathrm{ha}^{-1}\left(81.88 \mathrm{~kg} \cdot \mathrm{ha}^{-1}\right.$ ) and this difference was related to biomass yield and tissue $\mathrm{N}$ concentration. For Alamo, NF/GA001, and NF/GA992, N removal was $112 \%$ greater than that of Cave-in-Rock (Figure 2).

There was a year $\times$ genotype interaction $(P=0.0284)$ on $P$ removal (Table 3). Between years, $\mathrm{P}$ removal was

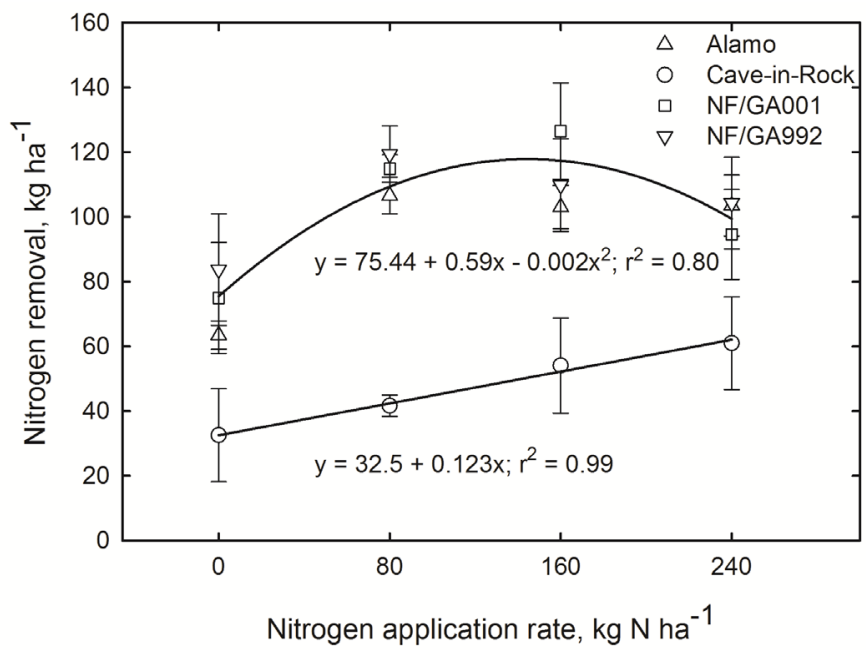

Figure 2. Genotype $\times$ N rate interaction effects on biomass yield of four switchgrass genotypes grown during 2008 and 2009 at the Brown Loam Branch Experiment Station, Raymond, MS.

Table 3. Means of P, K, Ca, Mg, and S removal rates among switchgrass genotypes and $\mathrm{N}$ rates during the 2008 and 2009 growing seasons at Brown Loam Branch Experiment Station, Raymond, MS.

\begin{tabular}{|c|c|c|c|c|c|c|c|}
\hline \multirow{3}{*}{ Treatment } & \multicolumn{7}{|c|}{ Nutrient Removal } \\
\hline & \multicolumn{2}{|c|}{$\mathrm{P}$} & \multicolumn{2}{|c|}{$\mathrm{K}$} & \multirow{2}{*}{$\mathrm{Ca}$} & \multirow{2}{*}{$\mathrm{Mg}$} & \multirow{2}{*}{$\mathrm{S}$} \\
\hline & 2008 & 2009 & 2008 & 2009 & & & \\
\hline Genotype & \multicolumn{7}{|c|}{$\longrightarrow \mathrm{kg} \cdot \mathrm{ha}^{-1}$} \\
\hline Alamo & $5.0 \mathrm{abA}^{\dagger}$ & $6.5 \mathrm{aA}$ & $17.5 \mathrm{~A}$ & $4.2 \mathrm{~B}$ & $18.8 \mathrm{a}$ & $14.5 \mathrm{a}$ & $3.7 \mathrm{a}$ \\
\hline Cave-in-Rock & $4.1 \mathrm{bA}$ & $3.3 \mathrm{bA}$ & $12.8 \mathrm{~A}$ & $1.7 \mathrm{~B}$ & $14.5 \mathrm{~b}$ & $7.1 \mathrm{~b}$ & $2.0 \mathrm{~b}$ \\
\hline NF/GA001 & $4.2 \mathrm{bB}$ & $7.4 \mathrm{aA}$ & $18.0 \mathrm{~A}$ & $5.8 \mathrm{~B}$ & $21.2 \mathrm{a}$ & $15.0 \mathrm{a}$ & $5.7 \mathrm{a}$ \\
\hline NF/GA992 & $7.0 \mathrm{aA}$ & $5.4 \mathrm{abA}$ & $20.2 \mathrm{~A}$ & $4.5 \mathrm{~B}$ & $20.7 \mathrm{a}$ & $16.4 \mathrm{a}$ & $4.3 \mathrm{a}$ \\
\hline \multicolumn{8}{|l|}{$\mathrm{N}$ rate } \\
\hline 0 & 4.2 & 5.2 & 13.1 & 3.0 & 13.8 & 9.1 & 2.7 \\
\hline 80 & 5.3 & 6.5 & 16.7 & 4.3 & 20.8 & 14.6 & 5.0 \\
\hline 160 & 4.8 & 5.1 & 17.8 & 5.1 & 21.6 & 14.8 & 4.1 \\
\hline 240 & 5.9 & 4.9 & 21.1 & 3.8 & 19.0 & 14.5 & 3.8 \\
\hline $\mathrm{OPC}^{\ddagger}$ & NS & NS & $\mathrm{L}^{* *}$ & NS & $\mathrm{L}^{* *}, \mathrm{Q}^{* * *}$ & $L^{*}, Q^{*}$ & $\mathrm{Q}^{* *}$ \\
\hline
\end{tabular}

${ }^{\dagger}$ Within column, means followed by the same lowercase letters, and within rows, means followed by the same uppercase letters are not different using PDIFF in SAS $(P>0.05)$; ${ }^{\ddagger}$ OPC, orthogonal polynomial contrast (L, linear; Q, quadratic); ${ }^{* * *},{ }^{* * *}$, significant at the $0.05,0.01$, and 0.001 levels, respectively; NS, not significant. 
similar for all genotypes except for NF/GA001, which had 68\% greater P removal in 2009 than 2008. In 2008, NF/GA992 had the greatest $P$ removal, while in 2009, Alamo, NF/GA001, and NF/GA992 had greater P removal than Cave-in-Rock (Table 3). There was no $\mathrm{N}$ rate effect on $\mathrm{P}$ removal; contrary to previous findings where $\mathrm{P}$ removal rates tended to increase with $\mathrm{N}$ rate [17]. There was a positive correlation between $\mathrm{P}$ removal and tissue P concentration $(P<0.0001)$.

There were genotype $(P=0.0280)$ and year $(P=0.0014)$ main effects on $\mathrm{K}$ removal but no $\mathrm{N}$ rate effect $(P>$ 0.05; Table 3), similar to previous findings [17]. In 2009, K removal was 76\% less than 2008 for all genotypes (Table 3). Cave-in-Rock K removal was less than the other genotypes in both years. These removal rates are less than those reported by Guretzky et al. [17].

Potassium removal was correlated with tissue $\mathrm{K}$ concentration $(P<0.0001)$. Calcium and $\mathrm{Mg}$ removal responded to $\mathrm{N}$ rate main effects (Table 3 ). Calcium removal increased by $51 \%$ from 0 to $80 \mathrm{~kg}^{\text {applied } \mathrm{N} \text { ha }}{ }^{-1}$, but further $\mathrm{N}$ applications did not result in increased Ca removal (Table 3).

Similarly, Mg removal increased by $60 \%$ as $\mathrm{N}$ application increased from 0 to $80 \mathrm{~kg} \mathrm{~N} \mathrm{ha}^{-1}$. Quadratic responses to $\mathrm{N}$ were observed for $\mathrm{Ca}\left(P=0.0004, r^{2}=0.99\right)$ and $\mathrm{Mg}\left(P=0.0484, r^{2}=0.95\right)$ concentrations.

Calcium removal was not correlated with Ca tissue concentration, however, $\mathrm{Mg}$ removal and Mg concentration were correlated $(P<0.0001)$. There was a genotype main effect on $\mathrm{S}$ removal $(P=0.0092)$. Cave-in-Rock $S$ removal was $55 \%$ less than the average of the other genotypes. A positive correlation was found between $S$ removal rate and tissue $\mathrm{S}$ concentration $(P<0.0001)$.

Nutrient removal rates in the biomass can be used to estimate fertilizer requirements of switchgrass [8]. Management practices such as cultivar selection [9] [10], N fertilizer application rate [12] [22], harvest frequency [8] [23], and harvest timing [8] [9] [22] may have an effect on the magnitude of nutrient removal from production systems and can be minimized by adopting the optimum combination of management factors.

\subsection{Nitrogen Use Indices}

There was genotype $\times \mathrm{N}$ rate interaction on both NUE $(P=0.0003)$ and ANR $(P=0.0265)$. Nitrogen use efficiency has been used to describe a plant's capacity to acquire and utilize $\mathrm{N}$ for producing biomass and is expressed as the biomass yield produced per unit $\mathrm{N}$ applied. NUE decreased monotonically above $80 \mathrm{~kg} \cdot \mathrm{ha}^{-1} \mathrm{~N}$ for all genotypes, except for Cave-in-Rock. Among genotypes, NUE varied in response to $\mathrm{N}$ application rate $(P<$ 0.0001) with a linear response observed for Cave-in-Rock and quadratic responses for Alamo, NF/GA001 and NF/GA992 (Figure 3(a)). Averaged across genotypes, NUE declined by 39\% from 80 to $160 \mathrm{~kg} \mathrm{~N}^{-1}$ and further decreased by $23 \%$ from 160 to $240 \mathrm{~kg} \mathrm{~N} \mathrm{ha}^{-1}$. At $80 \mathrm{~kg} \mathrm{~N} \mathrm{ha}^{-1}$, NUE for Cave-in-Rock was $50 \%$ less than other three genotypes (Figure 3(a)).

Alamo and the two experimental lines derived from Alamo, NF/GA001 and NF/GA992, therefore, were more efficient in utilizing $\mathrm{N}$ and converting to biomass production at this location. There were no further benefits to biomass yield at $\mathrm{N}$ rates above $80 \mathrm{~kg} \mathrm{ha}^{-1} \mathrm{~N}$, as a result, NUE decreased with increasing $\mathrm{N}$ application rates. Apparent $\mathrm{N}$ recovery responses were similar to NUE, that is, decreased with increasing $\mathrm{N}$ rate (Figure 3(b)). Among genotypes, ANR varied in response to $\mathrm{N}$ application rate $(P<0.0001)$ with a linear response observed for Cave-in-Rock and a quadratic response for Alamo, NF/GA001, and NF/GA992. Lemus et al. [7] reported 80\% $\mathrm{N}$ recovery at $90 \mathrm{~kg} \mathrm{ha}^{-1} \mathrm{~N}$ during a 3-yr period. This was more than $\mathrm{N}$ recovery rates found in our study for Alamo and the experimental lines at $80 \mathrm{~kg} \cdot \mathrm{ha}^{-1} \mathrm{~N}$, possibly in part due to the lesser biomass production and $\mathrm{N}$ removal. Stout et al. [24] reported lower $\mathrm{N}$ recovery rates of $31 \%$ and $23 \%$ for 90 and $180 \mathrm{~kg} \cdot \mathrm{ha}^{-1} \mathrm{~N}$, respectively. In our study, at $80 \mathrm{~kg} \cdot \mathrm{ha}^{-1} \mathrm{~N}$ Cave-in-Rock recovered $41 \%$ less $\mathrm{N}$ than the average recovery of the other three genotypes. Applications of $\mathrm{N}$ above $80 \mathrm{~kg} \cdot \mathrm{ha}^{-1}$ reduced recovery rates and may increase the potential for $\mathrm{N}$ leaching. Relatively less biomass yield and $\mathrm{N}$ recovery suggests that Cave-in-Rock is not suitable as a feedstock in the U.S. Midsouth.

\subsection{Cell Wall Constituents}

Acid detergent fiber, lignin, and hemicellulose concentrations were different among genotypes $(P<0.05)$ but there was no effect of $\mathrm{N}$ application rates $(P>0.05)$. There was a year $\times$ genotype effect on NDF $(P=0.0146)$ and cellulose $(P=0.0266)$ concentrations. Among genotypes, ADF was greatest in Cave-in-Rock, followed by the experimental lines and Alamo (Table 4). Hemicellulose and ash concentrations were the least in Cave-in-Rock and the greatest in NF/GA992 but similar in Alamo and NF/GA001. This interaction indicates that 


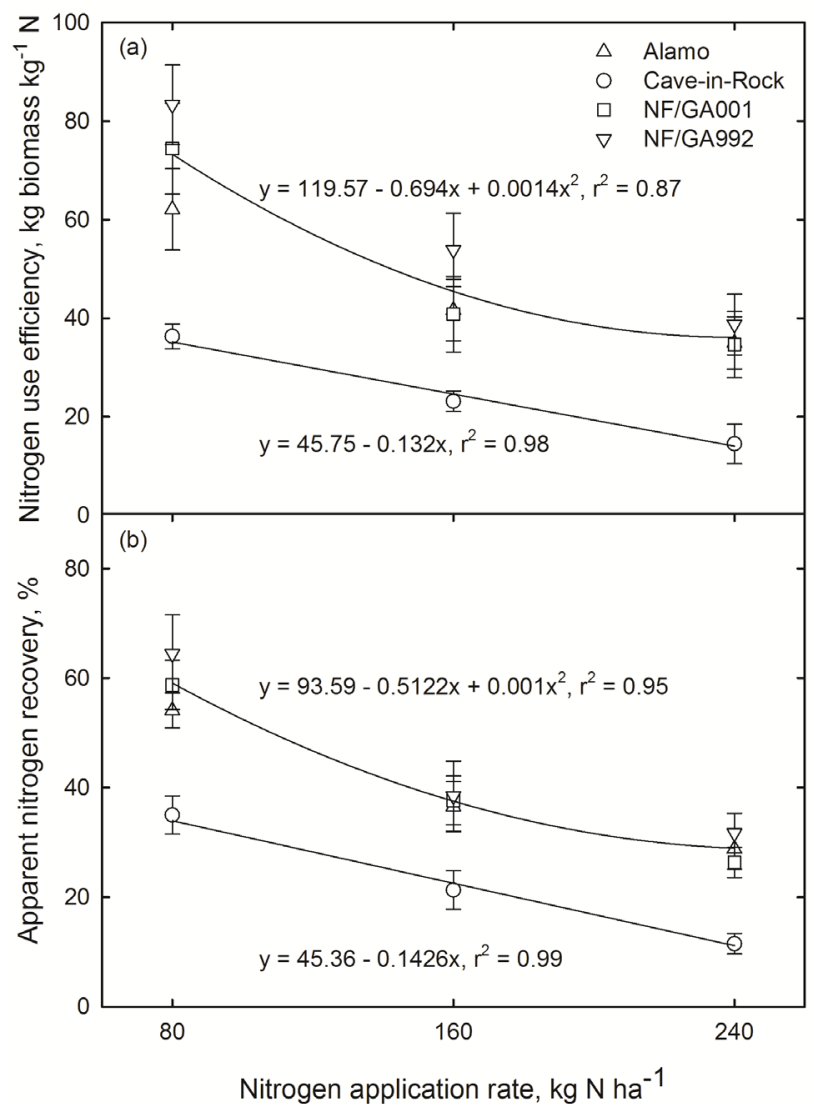

Figure 3. The effect of $\mathrm{N}$ application rate on (a) $\mathrm{N}$ use efficiency (NUE) and (b) apparent $\mathrm{N}$ recovery (ANR) of switchgrass averaged across 2008 and 2009 growing season, at the Brown Loam Branch Experiment Station, Raymond, MS. The symbols indicate the NUE and ANR across genotypes and the lines are fitted lines using a quadratic function for lowland genotypes and a linear function for upland Cave-in-Rock for NUE. The lines for ANR are fitted using a quadratic function for lowland genotypes and a linear function for upland Cave-in-Rock. Data are means and \pm SE of four replications.

Table 4. Cell wall components and ash of switchgrass genotypes during the 2008 and 2009 growing seasons at Brown Loam Branch Experiment Station, Raymond, MS.

\begin{tabular}{|c|c|c|c|c|c|c|c|c|}
\hline \multirow{2}{*}{ Genotype } & \multirow{2}{*}{$\mathrm{ADF}^{\dagger}$} & \multicolumn{2}{|c|}{ NDF } & \multirow{2}{*}{ Lignin } & \multicolumn{2}{|c|}{ Cellulose } & \multirow{2}{*}{ Hemicellulose } & \multirow{2}{*}{ Ash } \\
\hline & & 2008 & 2009 & & 2008 & 2009 & & \\
\hline & & & & & $\mathrm{kg}^{-1}$ & & - & \\
\hline Alamo & $536.4 \mathrm{c}$ & $831.9 \mathrm{cB}^{\ddagger}$ & $892.4 \mathrm{bA}$ & $121.1 \mathrm{~b}$ & 390.6 bB & 439.9 bA & $325.8 \mathrm{~b}$ & $82.3 \mathrm{~b}$ \\
\hline Cave-in-Rock & 551.9 a & 836.3 сB & $905.0 \mathrm{aA}$ & $125.4 \mathrm{a}$ & $401.6 \mathrm{aB}$ & $451.4 \mathrm{aA}$ & 318.8 c & $77.2 \mathrm{c}$ \\
\hline NF/GA001 & $544.9 \mathrm{~b}$ & 846.8 bB & $898.3 \mathrm{aA}$ & $124.3 \mathrm{ab}$ & $399.3 \mathrm{aB}$ & $442.5 \mathrm{bA}$ & $327.6 \mathrm{~b}$ & $80.2 \mathrm{~b}$ \\
\hline NF/GA992 & $545.0 \mathrm{~b}$ & $858.7 \mathrm{aB}$ & $903.3 \mathrm{aA}$ & $122.1 \mathrm{~b}$ & $402.8 \mathrm{aB}$ & $441.8 \mathrm{bA}$ & 336.7 a & $84.0 \mathrm{a}$ \\
\hline
\end{tabular}

${ }^{\dagger} \mathrm{ADF}$ = acid detergent fiber; NDF = neutral detergent fiber; ${ }^{\ddagger}$ Within column, means followed by the same lowercase letters, and within rows, means followed by the same uppercase letters are not different $(P>0.05)$ using PDIFF in SAS.

cell wall properties may change in different years in response to precipitation and temperature with genotypes responding dissimilarly.

Lignin concentration was greatest in the earliest maturing Cave-in-Rock (Table 4). These lignin results are greater than those reported previously [13]. Across all genotypes, NDF and cellulose increased by $6 \%$ and $10 \%$ from 2008 to 2009 (Table 4). Harvesting switchgrass after frost kill produced relatively large ADF and NDF 
concentrations, both highly desirable biofuel traits. Lowland genotypes had the greatest biomass yield and generally had the least lignin concentration, therefore may be more suitable for feedstock production in the U.S. Midsouth.

Ash concentration was different among genotypes $(P=0.0002)$. Cave-in-Rock had the least ash concentration while lowland NF/GA992 had the greatest ash concentration, suggesting that greater biomass yield led to an increase in ash concentration (Table 4). These results are contrary to previous reports [13] where lowland genotypes had the least ash concentration relative to upland genotypes. Nitrogen application rate did not have an effect on the cell wall composition in our study, supporting findings of Guretzky et al. [17] of only 1\% and 2\% increase in ADF and NDF as $\mathrm{N}$ rate increased from 0 to $225 \mathrm{~kg} \mathrm{~N} \mathrm{ha}^{-1}$ after a frost harvest for Alamo switchgrass. Lignin ( $r=0.69 ; P<0.0001$ and $r=0.98 ; P<0.0001)$ and cellulose $(r=0.60 ; P<0.0001$ and $r=0.92 ; P<$ $0.0001)$ concentration was positively correlated with ADF and NDF concentrations, respectively. Hemicellulose was positively correlated with only NDF $(r=0.53$; $P<0.0001$; Table 5$)$.

\subsection{Sugar Composition}

Carbohydrate concentrations in switchgrass were different due to both genotype and $\mathrm{N}$ rate main effects $(P<$ 0.05). Glucose, xylose and pentose represent the major components of cell-wall carbohydrates. Glucose concentration was similar between the two experimental lines, which were greater than Alamo and Cave-in-Rock (Table 6). Genotype NF/GA992 had the greatest arabinose, mannose and xylose concentrations but also had less starch and sucrose concentrations among all genotypes (Table 6). Arabinose concentration was different among all genotypes $(P<0.0001)$. Arabinose, pentose and xylose were the only sugars that responded to $\mathrm{N}$ application with their concentrations decreasing with increasing $\mathrm{N}$ rate (Table 6). Ethanol concentration, fructose and galactose were inversely correlated to ADF (Table 5). As lignin concentration increased, sugar concentrations decreased except for glucose.

Table 5. Significant correlation coefficients ( $P<0.05$, Pearson's correlation test) among switchgrass biomass yield, cell wall properties and ethanol yield of switchgrass averaged across the 2008 and 2009 growing seasons at Brown Loam Branch Experiment Station, Raymond, MS.

\begin{tabular}{|c|c|c|c|c|c|c|c|c|c|c|c|c|c|c|c|c|c|}
\hline & Yield & $\mathrm{ADF}^{\dagger}$ & NDF & Lig & Cell & Hemi & Ara. & ЕTOH & Fru. & Gal. & Glc. & Pent. & Sta. & Xyl. & Ash & TEY & TEP \\
\hline $\mathrm{ADF}$ & - & & & & & & & & & & & & & & & & \\
\hline NDF & - & 0.93 & & & & & & & & & & & & & & & \\
\hline Lig & - & 0.69 & 0.6 & & & & & & & & & & & & & & \\
\hline Cell & - & 0.98 & 0.92 & 0.55 & & & & & & & & & & & & & \\
\hline Hem & - & - & 0.53 & - & - & & & & & & & & & & & & \\
\hline Ara. & - & - & - & -0.74 & - & - & & & & & & & & & & & \\
\hline ЕТОН & - & -0.92 & -0.89 & -0.74 & -0.87 & - & - & & & & & & & & & & \\
\hline Fru. & - & -0.88 & -0.92 & -0.58 & -0.87 & - & - & 0.87 & & & & & & & & & \\
\hline Gal. & - & -0.87 & -0.81 & -0.75 & -0.82 & - & 0.61 & 0.74 & 0.71 & & & & & & & & \\
\hline Glc. & - & 0.91 & 0.97 & 0.54 & 0.91 & 0.5 & - & -0.81 & -0.91 & -0.8 & & & & & & & \\
\hline Pent. & - & 0.76 & 0.86 & - & 0.81 & 0.54 & - & -0.63 & -0.79 & -0.59 & 0.88 & & & & & & \\
\hline Sta. & -0.51 & - & -0.53 & - & - & -0.68 & -0.61 & - & 0.52 & - & -0.55 & -0.56 & & & & & \\
\hline Xyl. & - & 0.89 & 0.97 & - & 0.91 & 0.55 & - & -0.81 & -0.91 & -0.77 & 0.98 & 0.93 & -0.57 & & & & \\
\hline Ash & - & -0.82 & -0.82 & -0.57 & -0.81 & - & - & 0.66 & 0.7 & 0.94 & -0.82 & -0.72 & - & -0.83 & & & \\
\hline TEY & - & - & - & -0.7 & - & - & 0.58 & 0.68 & - & - & - & - & - & - & - & & \\
\hline TEP & 1 & - & - & - & - & - & - & - & - & - & - & - & -0.5 & - & - & - & \\
\hline TTEY & - & 0.82 & 0.92 & - & 0.84 & 0.57 & - & -0.68 & -0.83 & -0.8 & 0.96 & 0.9 & - & 0.96 & -0.87 & - & - \\
\hline TTEP & 1 & - & - & - & - & - & - & - & - & - & - & - & -0.52 & - & - & - & 0.99 \\
\hline
\end{tabular}

${ }^{\dagger} \mathrm{ADF}=$ acid detergent fiber; NDF = neutral detergent fiber; Lig = lignin; Cell = cellulose; Hemi = hemicellulose; Ara.= arabinose; ETOH = ethanol $\mathrm{g}^{-1}$ dry forage; Fru. = fructose; Gal. = galactose; Glu. = glucose; Pent. = pentose; Sta. = starch; Xyl. = xylose; TEY is the total ethanol yield from SSF; TEP is the total ethanol production per hectare from SSF; TTEY is the total theoretical ethanol yield (100\% conversion) and TTEP is the total theoretical ethanol yield production per hectare ( $100 \%$ conversion). 
Table 6. Composition of switchgrass genotypes averaged across the 2008 and 2009 growing seasons at Brown Loam Branch Experiment Station, Raymond, MS.

\begin{tabular}{|c|c|c|c|c|c|c|c|c|c|c|c|}
\hline Treatment & Ara. $^{\dagger}$ & ETOH & Fru. & Gal. & Glc. & Glcs. & Man. & Pent. & Sta. & Suc. & Xyl. \\
\hline Genotype & & & & & & $\mathrm{g} \cdot \mathrm{kg}^{-1}$ & & & & & \\
\hline Alamo & $24.3 \mathrm{~b}^{\ddagger}$ & $53.5 \mathrm{a}$ & $2.8 \mathrm{a}$ & $9.3 \mathrm{a}$ & $300.6 \mathrm{~b}$ & $3.2 \mathrm{a}$ & $8.8 \mathrm{~b}$ & $189.7 \mathrm{~b}$ & $5.3 \mathrm{~b}$ & $2.7 \mathrm{a}$ & $205.8 \mathrm{~b}$ \\
\hline Cave-in-Rock & $22.9 \mathrm{~d}$ & $49.1 \mathrm{~b}$ & $2.6 \mathrm{ab}$ & $8.5 \mathrm{~b}$ & $302.2 \mathrm{~b}$ & $3.2 \mathrm{a}$ & $8.7 \mathrm{~b}$ & 193.3 а & $6.7 \mathrm{a}$ & $1.5 \mathrm{~b}$ & $207.9 \mathrm{~b}$ \\
\hline NF/GA001 & $23.6 \mathrm{c}$ & $49.8 \mathrm{~b}$ & $1.9 a b$ & $8.8 \mathrm{~b}$ & 303.6 a & $2.7 \mathrm{a}$ & $8.6 \mathrm{~b}$ & $188.9 \mathrm{~b}$ & $5.0 \mathrm{~b}$ & $2.3 \mathrm{a}$ & $209.0 \mathrm{~b}$ \\
\hline NF/GA992 & $25.0 \mathrm{a}$ & $48.2 \mathrm{~b}$ & $1.3 \mathrm{~b}$ & $9.4 \mathrm{a}$ & $307.5 \mathrm{a}$ & $1.9 \mathrm{~b}$ & $9.4 \mathrm{a}$ & 195.2 a & $2.8 \mathrm{c}$ & $0.5 \mathrm{c}$ & $213.0 \mathrm{a}$ \\
\hline \multicolumn{12}{|l|}{$\mathrm{N}$ rate } \\
\hline 0 & 24.5 & 50.8 & 1.8 & 9.0 & 307.1 & 2.6 & 9 & 196.1 & 4.3 & 1.8 & 212.1 \\
\hline 80 & 23.9 & 50.3 & 2.3 & 9.0 & 302.5 & 3.0 & 8.8 & 191.6 & 4.9 & 1.9 & 208.8 \\
\hline 160 & 24.0 & 49.8 & 2.2 & 9.1 & 302.1 & 2.6 & 8.9 & 190.3 & 4.9 & 1.4 & 207.7 \\
\hline 240 & 23.4 & 50.0 & 2.2 & 8.9 & 302.3 & 2.7 & 8.7 & 189.1 & 5.7 & 2.0 & 207.2 \\
\hline Mean & & 50.2 & 2.1 & 9.0 & 303.5 & 2.7 & 8.9 & & & 1.8 & \\
\hline $\mathrm{OPC}^{\S}$ & $\mathrm{L} * \mathrm{Q}^{*}$ & NS & NS & NS & NS & NS & NS & $\mathrm{L}^{* *}, \mathrm{Q}^{* *}$ & $\mathrm{~L}^{*}, \mathrm{Q}^{*}$ & NS & $\mathrm{Q}^{*}$ \\
\hline
\end{tabular}

${ }^{\dagger}$ Ara. = arabinose, ETOH = ethanol g ${ }^{-1}$ dry forage; Fru. = fructose; Gal. = galactose; Glu. = glucose; Glcs. = soluble glucose; Man. = mannose; Pent. = pentose; Sta. = starch; Suc. = sucrose and Xyl. = xylose; ${ }^{\ddagger}$ Within column, means followed by the same lowercase letters are not different using PDIFF in SAS $(P>0.05) ;{ }^{\S} \mathrm{OPC}$, orthogonal polynomial contrast (L, linear; Q, quadratic; C, cubic); ${ }^{*},{ }^{* *},{ }^{* * *}$, significant at the 0.05 , 0.01 , and 0.001 levels, respectively; NS, not significant.

\subsection{Ethanol Yield}

There was a genotype $(P=0.0197)$ and $\mathrm{N}$ rate $(P=0.0161)$ main effect on TEY. Total ethanol yield was greatest in Alamo $\left(165.8 \mathrm{~L} \cdot \mathrm{Mg}^{-1}\right)$ and averaged $162.0 \mathrm{~L} \cdot \mathrm{Mg}^{-1}$ for the other three genotypes (Table 7). The TEY decreased linearly with $\mathrm{N}$ application rate $\left(\mathrm{y}=-1.64 \mathrm{x}+166.85, r^{2}=0.89\right)$.

There was a year $\times$ genotype $(P=0.0465)$ and year $\times \mathrm{N}$ rate $(P=0.0063)$ interaction effect on TEP. The year $\times$ genotype interaction is partly due to the lesser TEP in Cave-in-Rock in both years. The TEP also decreased linearly with $\mathrm{N}$ application rate in both years. The TEP is calculated from the biomass yield and therefore the trends in response to $\mathrm{N}$ application and genotype are similar to biomass yield trends. The TEP increase in 2009 was due mainly to the increase in the second year biomass yield.

Total ethanol yield was inversely related to lignin concentration and positively correlated with arabinose and ethanol concentration (Table 5). On the contrary, TEP was not correlated with the cell wall properties but was correlated to biomass yield (Table 5). Although, differences in biomass composition existed among the genotypes, biomass production was found to have a greater effect on ethanol yield than biomass composition. The selection of genotypes for a specific eco-edaphic zone can therefore be based primarily on biomass production [13] since differences in cell wall composition are not large enough to have a substantial effect on the biomass quality [16].

\subsection{Theoretical Ethanol Yield}

There was a year $\times$ genotype interaction effect on TTEY $(P=0.0422)$. In 2008, TTEY was similar across all genotypes but in 2009, Alamo had less TTEY than Cave-in-Rock, although neither was different from the two breeding lines (Table 7). Lack of $\mathrm{N}$ application effect on TTEY is supported by previous studies [16]. The TTEP of Alamo and the experimental lines averaged $4.1 \mathrm{~kL} \cdot \mathrm{ha}^{-1}$ in 2008 and $6.8 \mathrm{~kL} \cdot \mathrm{ha}^{-1}$ in 2009 while Cavein-Rock was 2.0 and $2.9 \mathrm{~kL} \cdot \mathrm{ha}^{-1}$ in 2008 and 2009 respectively (Table 7). Across genotypes, TTEP in 2009 was $61 \%$ greater than 2008 and was correlated with biomass yield. There was an $\mathrm{N}$ rate $\times$ year interaction $(P=$ 0.0031) effect on TTEP. During 2008, TTEP response to $\mathrm{N}$ application was linear but in 2009, the response was quadratic (Table 7). Total theoretical ethanol yield was positively correlated with ADF $(r=0.82 ; P<0.001)$, NDF ( $r=0.92 ; P<0.001)$, cellulose $(r=0.84 ; P<0.001)$, hemicellulose $(r=0.57 ; P<0.001)$, glucose $(r=0.96$; $P<0.001)$, pentose $(r=0.90 ; P<0.001)$, and xylose $(r=0.96 ; P<0.001)$ concentrations. Similar to TEP, the 
Table 7. Estimated and theoretical ethanol yield of switchgrass genotypes during the 2008 and 2009 growing seasons at Brown Loam Branch Experiment Station, Raymond, MS.

\begin{tabular}{|c|c|c|c|c|c|c|c|}
\hline \multirow{3}{*}{ Treatment } & \multicolumn{3}{|c|}{ Estimated Ethanol Yield and Production } & \multicolumn{4}{|c|}{ Theoretical Ethanol Yield and Production } \\
\hline & \multirow{2}{*}{$\mathrm{TEY}^{\dagger}$} & \multicolumn{2}{|c|}{ TEP } & \multicolumn{2}{|c|}{ TTEY } & \multicolumn{2}{|c|}{ TTEP } \\
\hline & & 2008 & 2009 & 2008 & 2009 & 2008 & 2009 \\
\hline Genotype & $\mathrm{L} \cdot \mathrm{Mg}^{-1}$ & \multicolumn{2}{|c|}{$\mathrm{kL} \cdot \mathrm{ha}^{-1}$} & \multicolumn{2}{|c|}{$\mathrm{L} \cdot \mathrm{Mg}^{-1}$} & \multicolumn{2}{|c|}{$\mathrm{kL} \cdot \mathrm{ha}^{-1}$} \\
\hline Alamo & 165.8 a & $1.6 \mathrm{aB}^{\ddagger}$ & $2.6 \mathrm{aA}$ & $393.3 \mathrm{aB}$ & $418.5 \mathrm{bA}$ & $3.7 \mathrm{aB}$ & $6.6 \mathrm{aA}$ \\
\hline Cave-in-Rock & $162.4 \mathrm{~b}$ & $0.9 \mathrm{bB}$ & $1.1 \mathrm{bA}$ & $390.2 \mathrm{aB}$ & $426.4 \mathrm{aA}$ & $2.0 \mathrm{bA}$ & $2.9 \mathrm{bA}$ \\
\hline NF/GA001 & $160.8 \mathrm{~b}$ & $1.8 \mathrm{aB}$ & $2.5 \mathrm{aA}$ & $395.5 \mathrm{aB}$ & $421.9 \mathrm{abA}$ & $4.2 \mathrm{aB}$ & $6.5 \mathrm{aA}$ \\
\hline NF/GA992 & $162.0 \mathrm{~b}$ & $1.8 \mathrm{aB}$ & $2.8 \mathrm{aA}$ & $398.9 \mathrm{aB}$ & $423.5 \mathrm{abA}$ & $4.4 \mathrm{aB}$ & $7.2 \mathrm{aA}$ \\
\hline \multicolumn{8}{|l|}{$\mathrm{N}$ rate } \\
\hline 0 & 165.9 & $1.2 \mathrm{~A}$ & $1.5 \mathrm{~A}$ & 399.1 & 425.8 & $2.7 \mathrm{~A}$ & $3.9 \mathrm{~A}$ \\
\hline 80 & 162.7 & $1.5 \mathrm{~B}$ & $2.7 \mathrm{~A}$ & 395.1 & 422.4 & $3.6 \mathrm{~B}$ & $6.9 \mathrm{~A}$ \\
\hline 160 & 161.6 & $1.6 \mathrm{~B}$ & $2.5 \mathrm{~A}$ & 391.6 & 421.9 & 3.9 B & $6.4 \mathrm{~A}$ \\
\hline 240 & 160.8 & $1.6 \mathrm{~B}$ & $2.2 \mathrm{~A}$ & 392.7 & 418.7 & 3.9 B & $5.6 \mathrm{~A}$ \\
\hline $\mathrm{OPC}^{\S}$ & $\mathrm{L}^{* *}$ & $\mathrm{~L}^{* *}$ & $L^{*}, Q^{* * *}$ & NS & NS & $\mathrm{L}^{* *}$ & $L^{*}, Q^{* * *}$ \\
\hline
\end{tabular}

${ }^{\dagger}$ TEY is the total ethanol yield from SSF, TEP is the total ethanol production per hectare from SSF, TTEY is the total theoretical ethanol yield (100\% conversion) and TTEP is the total theoretical ethanol yield production per hectare ( $100 \%$ conversion); ${ }^{\ddagger}$ Within column, means followed by the same lowercase letters, and within rows, means followed by the same uppercase letters are not different using PDIFF in SAS $(P>0.05)$; ${ }^{\S} \mathrm{OPC}$, orthogonal polynomial contrast (L, linear; Q, quadratic; C, cubic); ${ }^{* * *}{ }^{* * * *}$, significant at the $0.05,0.01$, and 0.001 levels, respectively; NS, not significant.

TTEP was correlated with biomass yield but not biomass composition (Table 5). Total ethanol yield from SSF and all biomass sugars did not correlate because of the differences in the methods of estimation. On the other hand, TEP from SSF and TTEP from all biomass sugars were correlated $(r=0.99)$ and both were also correlated with biomass yield $(r>0.99)$. Across all treatment combinations, TEP from SSF and all biomass sugars was 1.9 $\mathrm{kL}$ and $4.9 \mathrm{~kL}$, respectively. Total theoretical ethanol production from all biomass sugars therefore increased by factor of 2.5 relative to TEP from SSF.

These data suggests that there is potential to increase the ethanol output from lignocellulosic biomass. Current methods of conversion are affected by cell wall recalcitrance and therefore do not fully liberate the cellulose and hemicellulose from the lignin complex for chemical, microbial or enzymatic depolymerization [25] [26]. Moreover, current methods are not cost-effective to facilitate commercial biomass to ethanol conversion [26] [27]. The ethanol yield potential difference in our study is 231 (141\%) and $260 \mathrm{~L} \cdot \mathrm{Mg}^{-1}$ (160\%) in 2008 and 2009 , respectively. Developing novel pretreatment methods to maximize the cellulose accessibility to cellulase enzymes may lead to improved biofuel processing and lower the cost of these biomass-based fuels.

\section{Conclusion}

Nitrogen fertilizer application will be necessary to optimize and maintain feedstock yield and persistence in switchgrass production systems. Genotype and $\mathrm{N}$ application rate had an effect on biomass yield and nutrient removal. Nutrient removal was related to biomass yield and cultivar-inherent biomass production capacities and their responses to $\mathrm{N}$ rather than tissue nutrient concentration. Nitrogen use efficiency and ANR decreased with increased $\mathrm{N}$ application. Application rates above $80 \mathrm{~kg} \mathrm{~N}^{-1}$ reduced NUE and ANR and were likely to result in increased $\mathrm{N}$ leaching and volatilization. Biomass production, nutrient removal, NUE and ANR for Cave-inRock were less than Alamo and the two experimental lines derived from Alamo. Although compositional differences exist among genotypes, there is no effect of $\mathrm{N}$ application on cell wall properties and several sugars. The differences in biomass yield had greater importance than the differences in biomass quality. Ethanol yield was more closely related to biomass yield than the small differences in compositional traits among the genotypes. The differences between estimated and theoretical ethanol yield provide opportunities for improving the pretreatment techniques to maximize the ethanol output. Findings from this research can further aid in cultivar selection, feedstock quality control, agronomic management, and policy decisions. 


\section{Acknowledgements}

We thank Juan Solomon for assistance in field data collection and Dr. Rocky Lemus for assistance with NIRS analysis. This material is based upon work performed through the Sustainable Energy Research Center at Mississippi State University and is supported by the Department of Energy under Award Number DEFG3606G086025.

\section{Disclaimer}

This report was prepared as an account of work sponsored by an agency of the United States Government. Neither the United States Government nor any agency thereof, nor any of their employees, makes any warranty, express or implied, or assumes any legal liability or responsibility for the accuracy, completeness, or usefulness of any information, apparatus, product, or process disclosed, or represents that its use would not infringe privately owned rights. Reference herein to any specific commercial product, process, or service by trade name, trademark, manufacturer, or otherwise does not necessarily constitute or imply its endorsement, recommendation, or favoring by the United States Government or any agency thereof. The views and opinions of authors expressed herein do not necessarily state or reflect those of the United States Government or any agency thereof.

\section{References}

[1] Perlack, R.D., Wright, L.L., Turhollow, A.F., Graham, R.L., Stokes, B.J. and Erbach, D.C. (2005) Biomass as Feedstock for a Bioenergy and Bioproducts Industry: The Technical Feasibility of a Billion-Ton Annual Supply. Oak Ridge Natl. Lab, Oak Ridge.

[2] Sanderson, M., Reed, R., McLaughlin, S., Wullschleger, S., Conger, B., Parrish, D., Wolf, D., Taliaferro, C., Hopkins, A., Ocumpaugh, W., et al. (1996) Switchgrass as a Sustainable Bioenergy Crop. Bioresource Technology, 56, 83-93. http://dx.doi.org/10.1016/0960-8524(95)00176-X

[3] Jaynes, D.B., Colvin, T.S., Karlen, D.L., Cambardella, C.A. and Meek, D.W. (2001) Nitrate Loss in Subsurface Drainage as Affected by Nitrogen Fertilizer rate. Journal of Environmental Quality, 30, 1305-1314. http://dx.doi.org/10.2134/jeq2001.3041305x

[4] Glass, A.D.M. (2003) Nitrogen Use Efficiency of Crop Plants: Physiological Constraints upon Nitrogen Absorption. Critical Reviews in Plant Sciences, 22, 453-470. http://dx.doi.org/10.1080/07352680390243512

[5] Kingston-Smith, A.H., Bollard, A.L. and Minchin, F.R. (2006) The Effect of Nitrogen Status on the Regulation of Plant-Mediated Proteolysis in Ingested Forage: An Assessment Using Non-Nodulating White Clover. Annals of Applied Biology, 149, 35-42. http://dx.doi.org/10.1111/j.1744-7348.2006.00069.x

[6] Adler, P.R., Sanderson, M.A., Boateng, A.A., Weimer, P.J. and Jung, H.J.G. (2006) Biomass Yield and Biofuel Quality of Switchgrass Harvested in Fall or Spring. Agronomy Journal, 98, 1518-1525. http://dx.doi.org/10.2134/agronj2005.0351

[7] Lemus, R., Brummer, E.C., Moore, K.J., Molstad, N.E., Burras, C.L. and Barker, M.F. (2002) Biomass Yield and Quality of 20 Switchgrass Populations in Southern Iowa, USA. Biomass and Bioenergy, 23, 433-442. http://dx.doi.org/10.1016/S0961-9534(02)00073-9

[8] Reynolds, J.H., Walker, C.L. and Kirchner, M.J. (2000) Nitrogen Removal in Switchgrass Biomass under Two Harvest Systems. Biomass and Bioenergy, 19, 281-286. http://dx.doi.org/10.1016/S0961-9534(00)00042-8

[9] Fike, J.H., Parrish, D.J., Wolf, D.D., Balasko, J.A., Green, J.J.T., Rasnake, M. and Reynolds, J.H. (2006) Switchgrass Production for the Upper Southeastern USA: Influence of Cultivar and Cutting Frequency on Biomass Yields. Biomass and Bioenergy, 30, 207-213. http://dx.doi.org/10.1016/j.biombioe.2005.10.008

[10] Stroup, J.A., Sanderson, M.A., Muir, J.P., McFarland, M.J. and Reed, R.L. (2003) Comparison of Growth and Performance in Upland and Lowland Switchgrass Types to Water and Nitrogen Stress. Bioresource Technology, 86, 65-72. http://dx.doi.org/10.1016/S0960-8524(02)00102-5

[11] Vogel, K.P., Brejda, J.J., Walters, D.T. and Buxton, D.R. (2002) Switchgrass Biomass Production in the Midwest USA: Harvest and Nitrogen Management. Agronomy Journal, 94, 413-420. http://dx.doi.org/10.2134/agronj2002.0413

[12] Muir, J.P., Sanderson, M.A., Ocumpaugh, W.R., Jones, R.M. and Reed, R.L. (2001) Biomass Production of “Alamo” Switchgrass in Response to Nitrogen, Phosphorus, and Row Spacing. Agronomy Journal, 93, 896-901. http://dx.doi.org/10.2134/agronj2001.934896x

[13] Lemus, R., Parrish, D.J. and Abaye, O. (2008) Nitrogen-Use Dynamics in Switchgrass Grown for Biomass. Bioenergy Research, 1, 153-162. http://dx.doi.org/10.1007/s12155-008-9014-x

[14] Vogel, K.P., Dien, B.S., Jung, H.G., Casler, M.D., Masterson, S.D. and Mitchell, R.B. (2011) Quantifying Actual and 
Theoretical Ethanol Yields for Switchgrass Strains Using NIRS Analyses. BioEnergy Research, 4, 96-110. http://dx.doi.org/10.1007/s12155-010-9104-4

[15] SAS Institute (2008) The SAS system for Windows. Release 9.2. SAS Inst., Cary.

[16] Lemus, R., Brummer, E.C., Burras, C.L., Moore, K.J., Barker, M.F. and Molstad, N.E. (2008) Effects of Nitrogen Fertilization on Biomass Yield and Quality in Large Fields of Established Switchgrass in Southern Iowa, USA. Biomass and Bioenergy, 32, 1187-1194. http://dx.doi.org/10.1016/j.biombioe.2008.02.016

[17] Guretzky, J.A., Biermacher, J.T., Cook, B.J., Kering M.K. and Mosali, J. (2011) Switchgrass for Forage and Bioenergy: Harvest and Nitrogen Rate Effects on Biomass Yields and Nutrient Composition. Plant and Soil, 339, 69-81. http://dx.doi.org/10.1007/s11104-010-0376-4

[18] Alexopoulou, E., Sharma, N., Papatheohari, Y., Christou, M., Piscioneri, I., Panoutsou, C. and Pignatelli, V. (2008) Biomass Yields for Upland and Lowland Switchgrass Varieties Grown in the Mediterranean Region. Biomass and Bioenergy, 32, 926-933. http://dx.doi.org/10.1016/j.biombioe.2008.01.015

[19] Sanderson, M.A., Read, J.C. and Reed, R.L. (1999) Harvest Management of Switchgrass for Biomass Feedstock and Forage Production. Agronomy Journal, 91, 5-10. http://dx.doi.org/10.2134/agronj1999.00021962009100010002x

[20] Jung, G.A., Shaffer, J.A., Stout, W.L. and Panciera, M.T. (1990) Warm-Season Grass Diversity in Yield, Plant Morphology, and Nitrogen Concentration and Removal in Northeastern USA. Agronomy Journal, 82, 21-26. http://dx.doi.org/10.2134/agronj1990.00021962008200010005x

[21] Propheter, J. and Staggenborg, S. (2010) Performance of Annual and Perennial Biofuel Crops: Nutrient Removal during the First Two Years. Agronomy Journal, 102, 798-805. http://dx.doi.org/10.2134/agronj2009.0462

[22] Madakadze, I.C., Stewart, K.A., Peterson, P.R., Coulman, B.E. and Smith, D.L. (1999) Cutting Frequency and Nitrogen Fertilization Effects on Yield and Nitrogen Concentration of Switchgrass in a Short Season Area. Crop Science, 39, 552-557. http://dx.doi.org/10.2135/cropsci1999.0011183X003900020041x

[23] Thomason, W.E., Raun, W.R., Johnson, G.V., Taliaferro, C.M., Freeman, K.W., Wynn, K.J. and Mullen, R.W. (2004) Switchgrass Response to Harvest Frequency and Time and Rate of Applied Nitrogen. Journal of Plant Nutrition, 27, 1199-1226. http://dx.doi.org/10.1081/PLN-120038544

[24] Stout, W., Staley, T., Shaffer, J. and Jung, G. (1991) Quantitative Effects of Soil Depth and Soil and Fertilizer Nitrogen on Nitrogen Uptake by Tall Fescue and Switchgrass. Communications in Soil Science and Plant Analysis, 22, 16471660. http://dx.doi.org/10.1080/00103629109368525

[25] Jiang, H.-L., He, Q., He, Z., Hemme, C.L., Wu, L. and Zhou, J. (2013) Continuous Cellulosic Bioethanol Fermentation by Cyclic Fed-Batch Co-Cultivation. Applied Environmental Microbiology, 79, 1580-1589. http://dx.doi.org/10.1128/AEM.02617-12

[26] Yang, B. and Wyman, C.E. (2007) Pretreatment: The Key to Unlocking Low-Cost Cellulosic Ethanol. Biofuels, Bioproducts and Biorefining, 2, 26-40. http://dx.doi.org/10.1002/bbb.49

[27] Alvira, P., Tomás-Pejó, E., Ballesteros, M. and Negro, M. (2010) Pretreatment Technologies for an Efficient Bioethanol Production Process Based on Enzymatic Hydrolysis: A Review. Bioresource Technology, 101, 4851-4861. http://dx.doi.org/10.1016/j.biortech.2009.11.093

\section{Abbreviations}

ADF, acid detergent fiber;

ADL, acid detergent lignin;

ANR, apparent nitrogen recovery;

DM, dry matter;

ETOH, ethanol per gram dry forage;

NDF, neutral detergent fiber;

NIRS, near infrared spectroscopy;

NUE, nitrogen use efficiency;

OPC, orthogonal polynomial contrast;

SSF, simultaneous saccharification and fermentation;

TEP, theoretical ethanol production;

TEY, total ethanol production;

TTEP, total theoretical ethanol production;

TTEY, total theoretical ethanol yield. 